\title{
Relationship in chemical composition between mother solution and allophane-like aluminosilicate precipitate through neutralization of acid hydrothermal water by seawater
}

\author{
Kenji Nogami \\ Kusatsu-Shirane Volcano Observatory, Volcanic Fluid Research Center, Tokyo Institute of Technology, \\ 641-36 Kusatsu, Agatsuma, Gunma 377-1711, Japan
}

(Received September 17, 2003; Revised March 12, 2004; Accepted March 12, 2004)

\begin{abstract}
A series of experiments on the formation of allophane-like aluminosilicate precipitates were carried out through neutralization of acid solutions in variety of relative proportions of $\mathrm{Si}, \mathrm{Fe}$ and $\mathrm{Al}$ by seawater. The retrieval and decomposition procedures were available for precise determination of those components in the precipitates. Iron in the mother solutions was completely precipitated and Al was mostly precipitated, however, Si was partly coprecipitated with iron and aluminum. Iron and/or Al coexisting with Si caused a remarkable rise of the precipitated proportion of $\mathrm{Si}$. This was ascribed to co-precipitation of these components on the formation of the precipitates. Difference in effect on the precipitated proportion of $\mathrm{Si}$ between $\mathrm{Fe}$ and $\mathrm{Al}$ was not noticeable. This result indicated equivalence of $\mathrm{Fe}$ to $\mathrm{Al}$ on the formation of the precipitates through neutralization. The correlations in the $(\mathrm{Fe}+\mathrm{Al}) / \mathrm{Si}$ and the $\mathrm{Fe} / \mathrm{Al}$ molar ratios between the mother solution and the precipitates strongly designated that the relative proportions of $\mathrm{Si}, \mathrm{Fe}$ and $\mathrm{Al}$ in hydrothermal water discharged from submarine volcanoes were able to be determined uniquely through chemical analysis of the precipitates causing discolored seawater.
\end{abstract}

Key words: Precipitate, co-precipitation, neutralization, acid water, seawater.

\section{Introduction}

Precipitation of minerals from hydrothermal water is frequently occurred due to change in chemical and physical conditions. Decrease in water temperature makes the solubility of aqueous silica low, which results in formation of silica scale and siliceous sinter. Neutralization is one of the causes of mineral precipitation. Allophane-like iron-bearing aluminosilicates form along the seashore of Satsuma-Iwojima in southern Kyushu, Japan resulting from neutralization of acid thermal water by seawater (e.g. Kamada et al., 1964).

Many active submarine and insular volcanoes are distributed on Izu-Mariana and Ryukyu arcs in the northwestern Pacific Ocean. The surface of the sea above their craters is discolored to white, light blue, yellow and reddish brown, which is frequently observed on submarine volcanic activity. It is owing to suspension of the same allophane-like aluminosilicate precipitates that form at Satsuma-Iwojima (Ossaka, 1975). Further, Ossaka et al. (1977) proved that the allophane-like precipitates are formed by coprecipitation of $\mathrm{Si}, \mathrm{Al}$ and $\mathrm{Fe}$ hydroxides through neutralization of acid thermal water by seawater. Although over $90 \%$ of $\mathrm{Al}$ and $\mathrm{Fe}$ in acid thermal water are deposited at $\mathrm{pH}$ values of mother solution higher than 6 , only about $30 \%$ of $\mathrm{Si}$ in acid water co-precipitates with Fe and Al (Ossaka et al., 1977; Nogami et al., 1993).

Fukutoku-Oka-no-Ba submarine volcano located on Izu-

Copy right (c) The Society of Geomagnetism and Earth, Planetary and Space Sciences (SGEPSS); The Seismological Society of Japan; The Volcanological Society of Japan; The Geodetic Society of Japan; The Japanese Society for Planetary Sciences; TERRAPUB.
Mariana arc at about $1300 \mathrm{~km}$ southward from Tokyo is one of most active submarine volcanoes in Japan. Violent eruptions with formation of new islands have often occurred there. A new island was temporally formed on the phreatomagmatic eruption in 1986, however, wave erosion vanished it in about two months and its activity has been dormant since then. The surface of the sea above the crater is always discolored, which indicates that acid hydrothermal water is always discharged from the crater of this submarine volcano even in a dormant period.

Discolored seawater has been collected there several times. In 1977 and 1979 when the volcanic activity was dormant, the precipitates enriched in $\mathrm{Si}$ relative to $\mathrm{Fe}$ and $\mathrm{Al}$ discolored the surface of the sea to milky white and light blue. During the 1986 eruption, color of the surface of the sea was drastically changed into reddish and/or yellowish and the precipitates became enriched in $\mathrm{Fe}$ and $\mathrm{Al}$ relative to Si. After ceasing the eruption, relative proportions of the components in the precipitates and color of the surface of the sea returned to those in the dormant period (Ossaka et al., 1996).

This example shows good correspondence of chemical composition of the precipitates to submarine volcanism. Although the relative proportions of $\mathrm{Si}, \mathrm{Fe}$ and $\mathrm{Al}$ in the precipitates are different from those in the mother solutions, they designate chemical characteristics of hydrothermal water discharged from submarine volcanoes. Consequently, change in chemical composition of hydrothermal water corresponding to activation of submarine volcanism is detectable through analysis of the precipitates.

In this study, neutralization experiments reproduce alumi- 
Table 1. Concentration (in $\mathrm{mg} / \mathrm{kg}$ ) of $\mathrm{Si}, \mathrm{Fe}$ and $\mathrm{Al}$ in acid solutions and seawater prepared for the neutralization experiments.

\begin{tabular}{cccc}
\hline & $\mathrm{Si}$ & $\mathrm{Fe}$ & $\mathrm{Al}$ \\
\hline Si solution & 172 & 11.9 & 60.7 \\
Fe solution & 0 & 913 & 0 \\
Al solution & 0 & 0 & 927 \\
Seawater & 0.2 & 0 & 0 \\
\hline
\end{tabular}

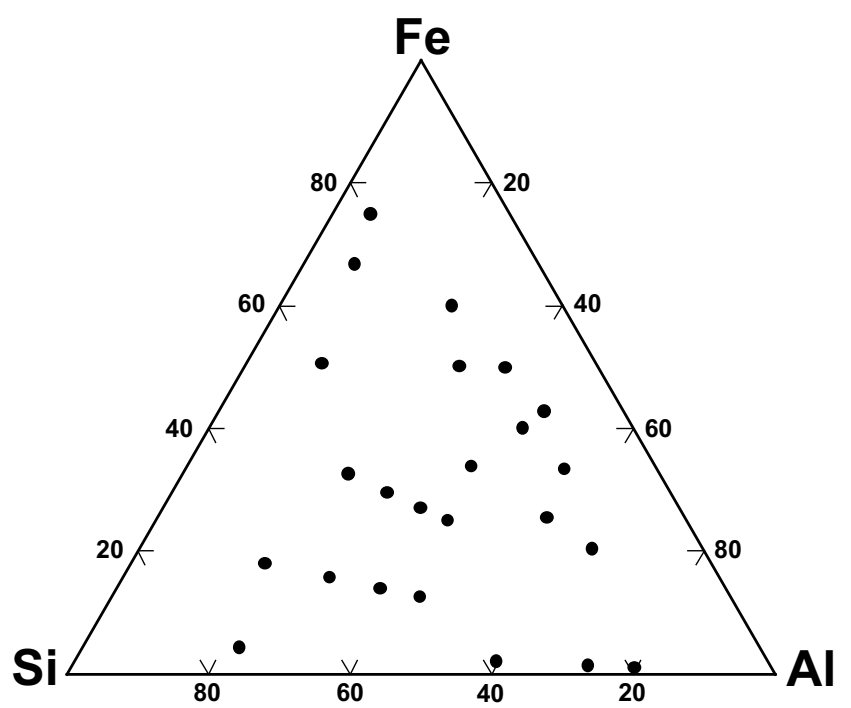

Fig. 1. Relative proportions (in wt.\%) of $\mathrm{Si}, \mathrm{Fe}$ and $\mathrm{Al}$ in the mother solutions.

nosilicate precipitates in variety of the relative proportions of $\mathrm{Si}, \mathrm{Fe}$ and Al. They are aimed to show relationship in the relative proportions of these components between mother solution and aluminosilicate precipitate.

\section{Experiments}

\subsection{Preparation}

Si solution: Acid solution of high Si content is very hard for preparation artificially and acid thermal water $\left(95^{\circ} \mathrm{C}, \mathrm{pH}\right.$ 1.61) of high Si concentration collected at Bandaiko hot spring in Kusatsu Spa, Gunma, Japan is used for Si solution.

Fe solution: Iron spices in natural acid thermal water are divalent and trivalent. Oxidation of $\mathrm{Fe}$ (II) to Fe (III) is very easy at neutral $\mathrm{pH}$ and trivalent iron results in the predominant species in the neutralized solutions. Hence, iron solution is simply prepared by dissolution of $\mathrm{FeCl}_{3}$ into $0.02 \mathrm{M}$ $\mathrm{HCl}$ (approx. $1000 \mathrm{mg} \mathrm{l}^{-1}$ ).

Al solution: Al solution is prepared by dissolution of $\mathrm{Al}_{2}\left(\mathrm{SO}_{4}\right) 3 \cdot 14 \sim 18 \mathrm{H}_{2} \mathrm{O}$ into $0.02 \mathrm{M} \mathrm{HCl}$ (approx. $1000 \mathrm{mg}$ $\left.1^{-1}\right)$.

Seawater: Seawater filtrated through $5 \mathrm{~A}$ filter paper has a pH of 8.21.

Concentration of $\mathrm{Fe}, \mathrm{Al}$ and $\mathrm{Si}$ in these solutions and seawater are strictly determined by ICP emission spectrometry (Table 1).

\subsection{Experimental procedures}

Aluminosilicate precipitates in variety of the relative proportions of $\mathrm{Si}, \mathrm{Fe}$ and $\mathrm{Al}$ are produced through neutralization of acid solutions by seawater. The acid solutions are
Table 2. Formula for preparation of acid solutions and seawater (in $\mathrm{ml}$ ) for the experiments.

\begin{tabular}{ccccc}
\hline Exp & Si & Fe & Al & Seawater \\
\hline$\# 1$ & 1.00 & 0.30 & 0 & 200 \\
$\# 2$ & 1.00 & 0.60 & 0 & 200 \\
$\# 3$ & 1.00 & 0.90 & 0 & 200 \\
$\# 4$ & 1.00 & 0 & 0.30 & 200 \\
$\# 5$ & 1.00 & 0 & 0.60 & 200 \\
$\# 6$ & 1.00 & 0 & 0.90 & 200 \\
$\# 7$ & 1.00 & 0.30 & 0.30 & 200 \\
$\# 8$ & 1.00 & 0.30 & 0.60 & 200 \\
$\# 9$ & 1.00 & 0.30 & 0.90 & 200 \\
$\# 10$ & 1.00 & 0.60 & 0.30 & 200 \\
$\# 11$ & 1.00 & 0.60 & 0.60 & 200 \\
$\# 12$ & 1.00 & 0.60 & 0.90 & 200 \\
$\# 13$ & 1.00 & 0.90 & 0.30 & 200 \\
$\# 14$ & 1.00 & 0.90 & 0.60 & 200 \\
$\# 15$ & 1.00 & 0.90 & 0.90 & 200 \\
$\# 16$ & 4.00 & 0.20 & 0 & 500 \\
$\# 17$ & 4.00 & 0.20 & 0.20 & 500 \\
$\# 18$ & 4.00 & 0.20 & 0.40 & 500 \\
$\# 19$ & 4.00 & 0.20 & 0.60 & 500 \\
$\# 20$ & 4.00 & 0 & 0 & 500 \\
$\# 21$ & 4.00 & 0.60 & 0.20 & 500 \\
\hline 23 & 4.00 & 0.60 & 0.40 & 500 \\
\hline 13 & 4.00 & 0.60 & 0.60 & 500 \\
\hline 1.00 & 0.60 & 0.80 & 500 \\
\hline \#2 & & & &
\end{tabular}

prepared by mixing of the $\mathrm{Si}, \mathrm{Fe}$ and $\mathrm{Al}$ solutions.

Transfer the $\mathrm{Si}, \mathrm{Fe}$ and $\mathrm{Al}$ solutions to $500 \mathrm{ml}$ beakers according to the formula shown in Table 2. Add the filtrated seawater to the $500 \mathrm{ml}$ beakers correctly using a $100 \mathrm{ml}$ hole pipette. After Ossaka et al. (1977), these mother solutions are allowed to stand quietly at room temperature for three days, which results in forming a small amount of the precipitates. Figure 1 shows wide variation of the mother solutions in the relative proportions of $\mathrm{Si}, \mathrm{Fe}$ and $\mathrm{Al}$.

\subsection{Analytical procedures}

For the experiments from \#1 to \#15, filtrate the solutions to a $250 \mathrm{ml}$ measuring flask through a $5 \mathrm{C}$ filter. Silicon, $\mathrm{Fe}$ and $\mathrm{Al}$ contents in the filtered solutions are diluted with distilled water and determined and $\mathrm{pH}$ values of the solutions are measured. For the other experiments, only $\mathrm{pH}$ values of the solutions are measured after filtration through a $5 \mathrm{C}$ filter.

The precipitate is subjected to decomposition according to the following scheme. Put the $5 \mathrm{C}$ filter paper with the precipitate into a $100 \mathrm{ml}$ beaker. Add exactly five $\mathrm{ml}$ of $1 \mathrm{M}$ $\mathrm{HCl}$ solution to the beaker with about $5 \mathrm{ml}$ of pure water. Warm this acid solution by a microwave oven for 30 seconds to dissolve the precipitate. Repeat this warming procedure thrice at intervals of 2 minutes. This interval avoids boiling the acid solution. Transfer the solution to a $100 \mathrm{ml}$ measuring flask through a 5A filter paper after cooling. Add correctly five $\mathrm{ml}$ of $1 \mathrm{M} \mathrm{HCl}$ solution to the beaker with about $5 \mathrm{ml}$ of pure water again and repeat the dissolution procedure once 


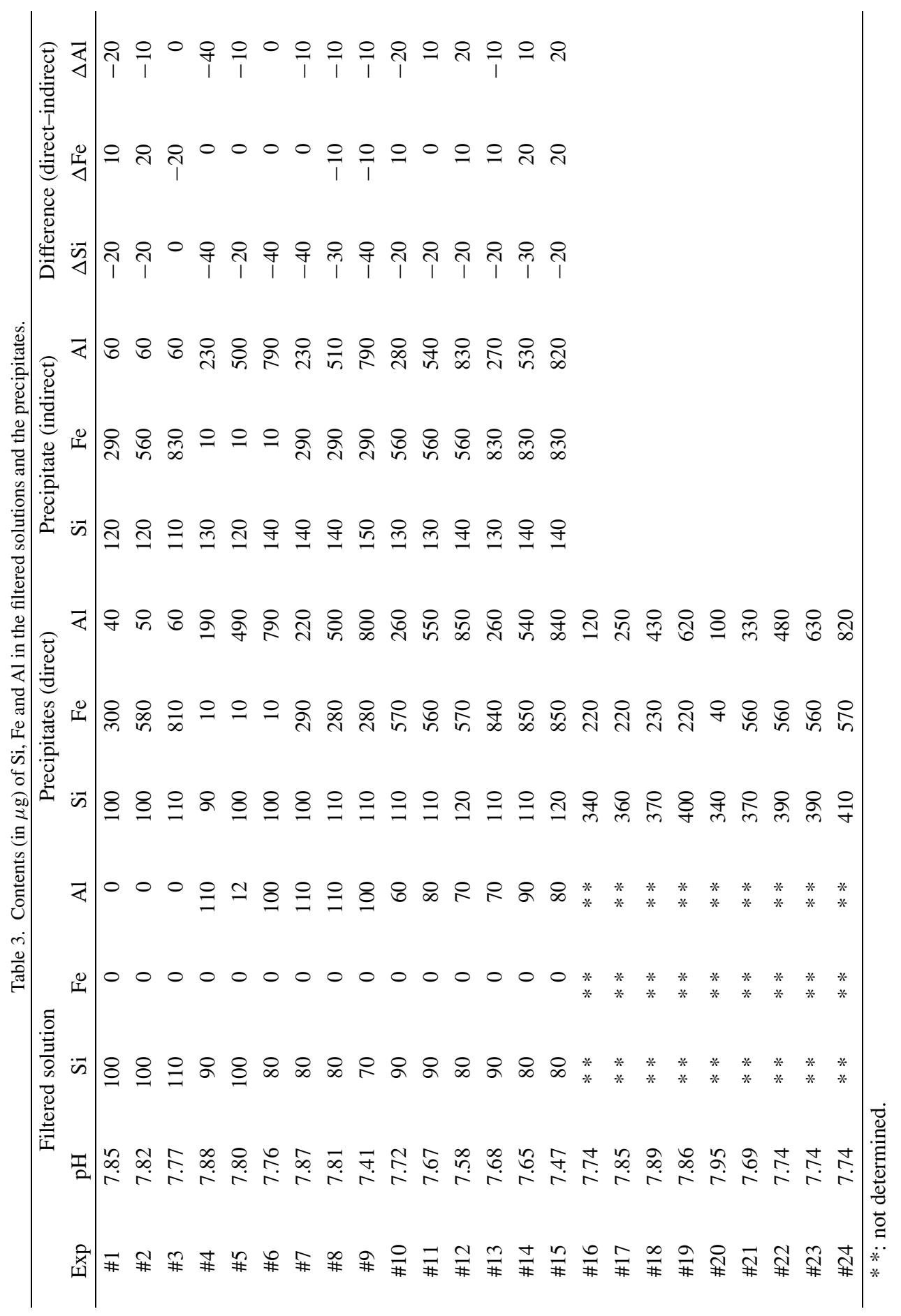




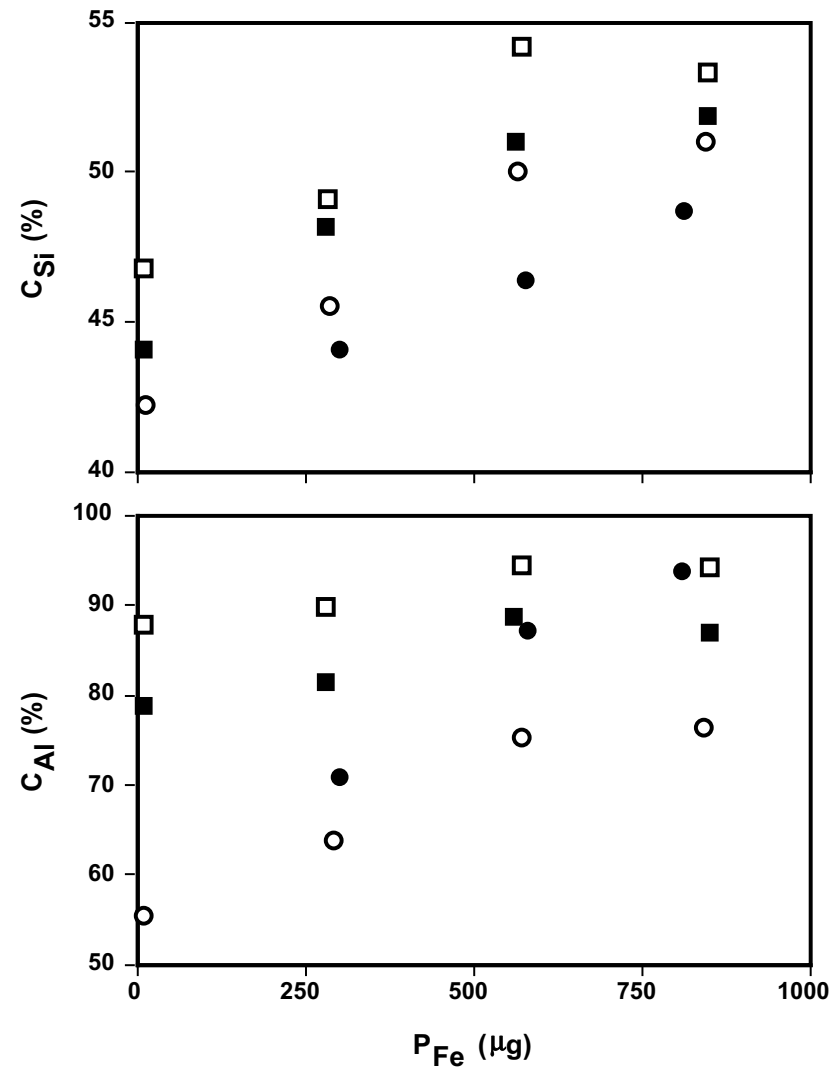

Fig. 2. Change in $\mathrm{C}_{\mathrm{Al}}$ and $\mathrm{C}_{\mathrm{Si}}$ plotted against $\mathrm{P}_{\mathrm{Fe}}$ with variation of $\mathrm{I}_{\mathrm{Al}}$.
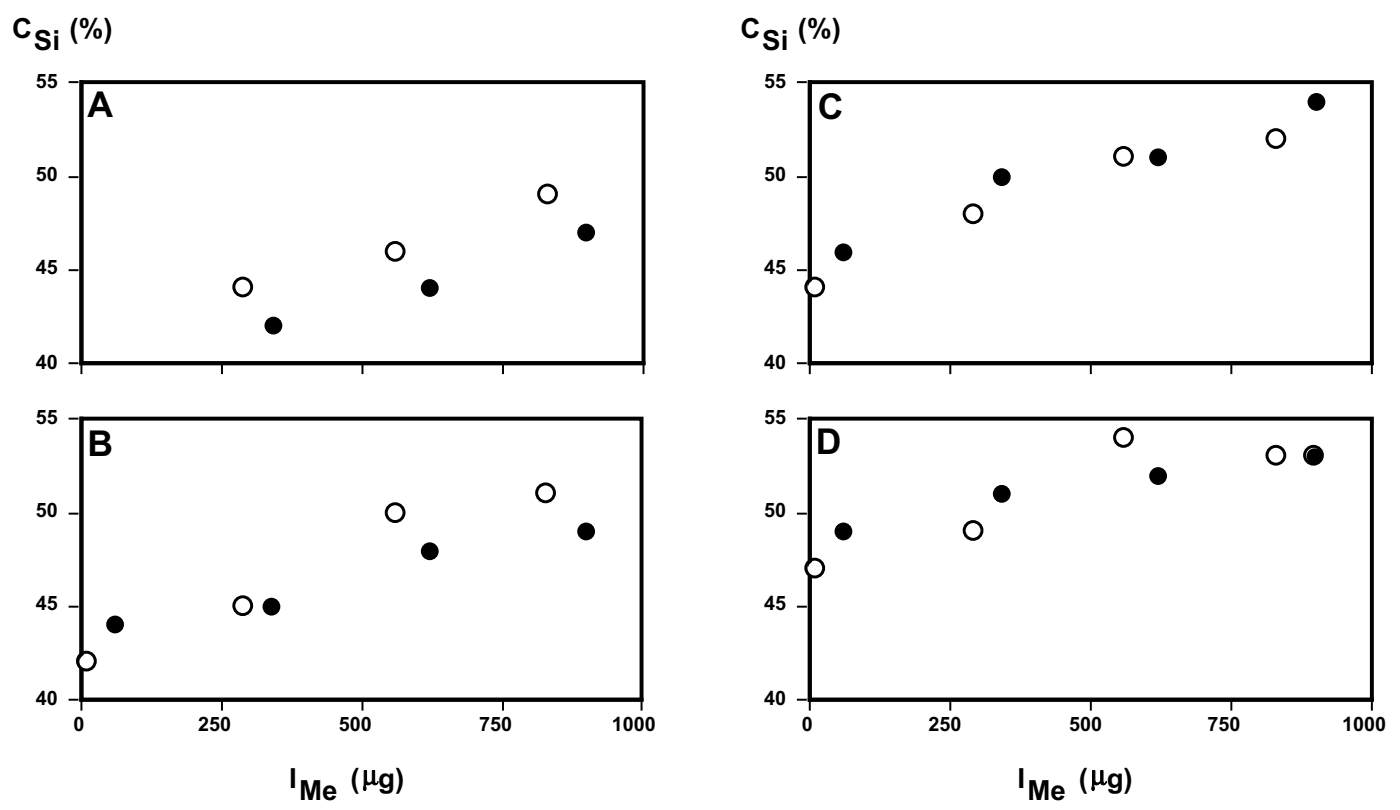

Fig. 3. Change in $\mathrm{C}_{\mathrm{Si}}$ plotted against $\mathrm{I}_{\mathrm{Me}}$. $\mathrm{Me}=\mathrm{Al}$ and Fe. $\bigcirc: \mathrm{C}_{\mathrm{Si}}$ against $\mathrm{I}_{\mathrm{Fe}}$ with $\left.\left.\left.\mathrm{A}\right) \mathrm{I}_{\mathrm{Al}}=60 \mu \mathrm{g}, \mathrm{B}\right) \mathrm{I}_{\mathrm{Al}}=340 \mu \mathrm{g}, \mathrm{C}\right) \mathrm{I}_{\mathrm{Al}}=620 \mu \mathrm{g}$ and D) $\mathrm{I}_{\mathrm{Al}}=900 \mu \mathrm{g}$. : $\mathrm{C}_{\mathrm{Si}}$ against $\mathrm{I}_{\mathrm{Al}}$ with A) $\left.\left.\mathrm{I}_{\mathrm{Fe}}=10 \mu \mathrm{g}, \mathrm{B}\right) \mathrm{I}_{\mathrm{Fe}}=290 \mu \mathrm{g}, \mathrm{C}\right) \mathrm{I}_{\mathrm{Fe}}=560 \mu \mathrm{g}$ and D) $\mathrm{I}_{\mathrm{Fe}}=830 \mu \mathrm{g}$.

more. Wash the beaker and the 5A filter paper thoroughly and diluted with distilled water.

Concentrations of $\mathrm{Si}, \mathrm{Fe}$, and $\mathrm{Al}$ in the $0.1 \mathrm{M} \mathrm{HCl}$ solutions and the filtered solutions are determined by ICP emission spectrometry. Experimental error for determination of $\mathrm{Si}, \mathrm{Fe}$ and $\mathrm{Al}$ is $1 \pm 0.05 \mathrm{mgl}^{-1}$. A pH meter with a glass electrode is used for $\mathrm{pH}$ measurement.

\section{Results and Discussion}

The $\mathrm{pH}$ values of the filtered solutions and the contents of $\mathrm{Si}, \mathrm{Fe}$ and $\mathrm{Al}$ in the filtered solutions and the precipitates are shown in Table 3. Difference in the contents of these components between the prepared solutions and the filtered solutions is also listed in Table 3 .

All the solutions have $\mathrm{pH}$ values higher than 7 . Ferrous ion 


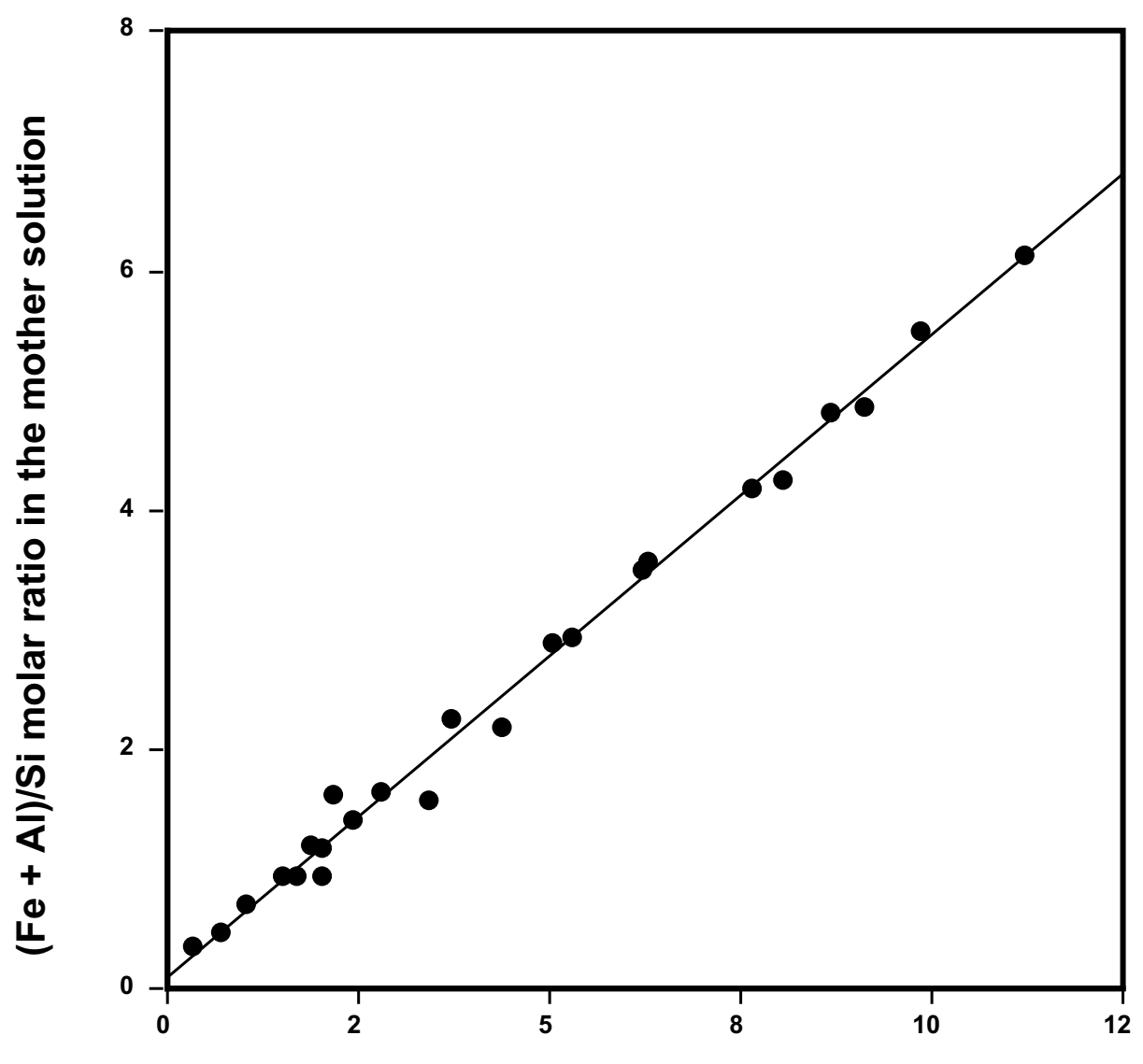

$(\mathrm{Fe}+\mathrm{Al}) / \mathrm{Si}$ molar ratio in the precipitate

Fig. 4. Relationship in $(\mathrm{Fe}+\mathrm{Al}) / \mathrm{Si}$ molar ratio between the mother solution and the precipitate. Regression line is expressed as $(\mathrm{Fe}+\mathrm{Al}) / \mathrm{Si}$ mother $=$ $0.102+0.53(\mathrm{Fe}+\mathrm{Al}) / \mathrm{Si}_{\text {prep }}$.

partly included in the mother solutions must be completely oxidized to ferric ion at these $\mathrm{pH}$ values, which makes the solubility of iron ion in the mother solutions extremely low. Difference in the contents of these components in the precipitates between the two determinations listed in Table 3 is $40 \mu \mathrm{g}$ for $\mathrm{Si}$ and $20 \mu \mathrm{g}$ for $\mathrm{Fe}$ and $\mathrm{Al}$ at most. These results show that analytical procedure shown in Section 2.3 enables to determine contents of three components in the precipitates with good precision in the light of the experimental error. Formerly, the precipitates were dissolved into coexistent seawater by addition of conc. $\mathrm{HCl}$ in the decomposition procedure on chemical analysis of discolored seawater. Hence, the samples had very high salinity and it made the precise determination of those components difficult. The retrieval and decomposition procedures shown in Section 2.3 help chemical analysis of discolored seawater samples hereafter.

Precipitated proportion of component $X, C x$, calculated by the following equation, $C x=P x \cdot I x^{-1} \cdot 100$, where $X$ is $\mathrm{Si}, \mathrm{Fe}$ and Al. $P x$ is the content of component $X$ in the precipitate and $I x$ is the content of component $X$ in the mother solution. Iron in the mother solutions is completely precipitated in all the experiments. Although $\mathrm{C}_{\mathrm{Al}}$ is slightly lower than $\mathrm{C}_{\mathrm{Fe}}$, more than $70 \%$ of $\mathrm{Al}$ in the mother solutions is precipitated and $\mathrm{C}_{\mathrm{Al}}$ rises as $\mathrm{I}_{\mathrm{Al}}$ increases. On the other hand, $\mathrm{C}_{\mathrm{Si}}$ ranges from $40 \%$ to $55 \%$ and it is somewhat higher than the results of the previous works by Ossaka et al. (1977) and Nogami et al. (1993).

Variation of $\mathrm{C}_{\mathrm{Al}}$ and $\mathrm{C}_{\mathrm{Si}}$ with $\mathrm{P}_{\mathrm{Fe}}$ is shown in Fig. 2. Increase of $\mathrm{P}_{\mathrm{Fe}}$ raises $\mathrm{C}_{\mathrm{Si}}$ and $\mathrm{C}_{\mathrm{Al}}$ markedly. Further, increase of $\mathrm{P}_{\mathrm{Al}}$ also raises $\mathrm{C}_{\mathrm{Si}}$ clearly. Coexistence of $\mathrm{Fe}$ and/or $\mathrm{Al}$ with $\mathrm{Si}$ raises $\mathrm{C}_{\mathrm{Si}}$ markedly, which is attributed to formation of the precipitates by co-precipitation of these components.

Variation of $\mathrm{C}_{\mathrm{Si}}$ as a function of $\mathrm{I}_{\mathrm{Fe}}$ is shown in Fig. 3 with changing $\mathrm{I}_{\mathrm{Al}}$ from 60 to $900 \mathrm{mg}$. $\mathrm{C}_{\mathrm{Si}}$ as a function of $\mathrm{I}_{\mathrm{Al}}$ is also plotted in the same figure with changing $\mathrm{I}_{\mathrm{Fe}}$ from 10 to $830 \mathrm{mg}$. These plots of $\mathrm{C}_{\mathrm{Si}}$ against $\mathrm{I}_{\mathrm{Fe}}$ and $\mathrm{I}_{\mathrm{Al}}$ designate that difference in effect on $\mathrm{C}_{\mathrm{Si}}$ between $\mathrm{I}_{\mathrm{Fe}}$ and $\mathrm{I}_{\mathrm{Al}}$ is not noticeable. Trivalent iron is capable of forming octahedrally co-ordinated hydrolyzed species like trivalent Al in weakly alkaline solution (Ichikuni, 1970). Figure 3 clearly shows that trivalent iron is equivalent to aluminum on the formation of the precipitates.

Figure 4 shows a correlation in $(\mathrm{Fe}+\mathrm{Al}) / \mathrm{Si}$ molar ratio between the mother solutions and the precipitates. The correlation coefficient is 0.996 . This relation strongly indicates that the molar ratio in hydrothermal water discharged from a submarine volcano can be estimated from the ratio in precipitate. This result also designates the equivalence between $\mathrm{Fe}$ and $\mathrm{Al}$ on the formation of the precipitates. Furthermore, correlation in the molar ratio of $\mathrm{Fe}$ to $\mathrm{Al}$ between the mother solution and the precipitate is also significant (Fig. 5). The 


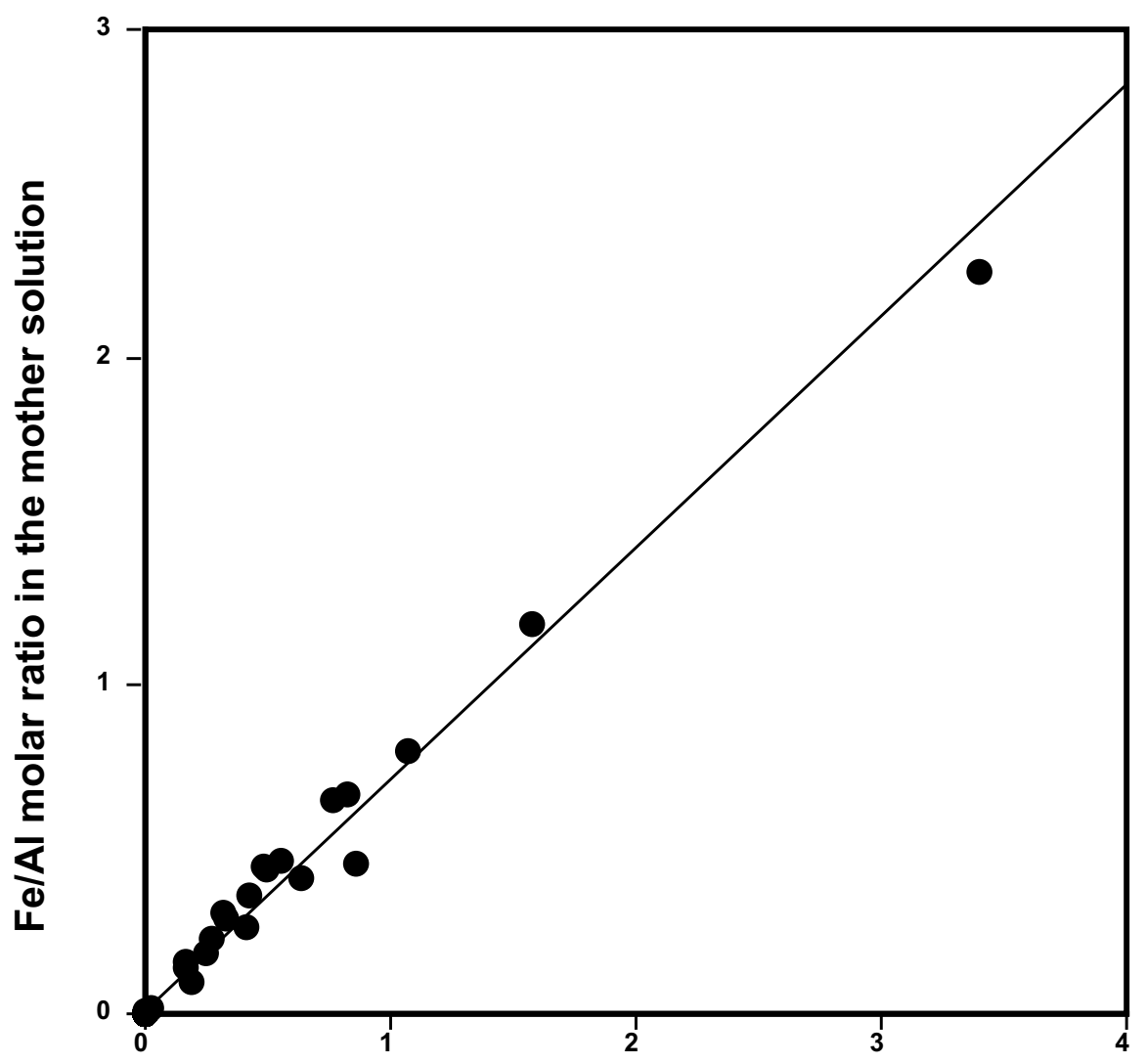

Fe/Al molar ratio in the precipitates

Fig. 5. Relationship in Fe/Al molar ratio between the mother solution and the precipitate. Regression line is expressed as $(\mathrm{Fe} / \mathrm{Al})_{\operatorname{mother}}=0.041+0.67$ $(\mathrm{Fe} / \mathrm{Al})_{\text {prep. }}$.

$\mathrm{Fe} / \mathrm{Al}$ molar ratios in the precipitates formed on the submarine volcanic activity in the past were less than 4 and the regression line is calculated except the experiments \#2 and \#3. The correlation coefficient is 0.991 . This result shows that the Fe/Al ratio in hydrothermal water can be estimated from the ratio in the precipitate. These correlations in the (Fe $+\mathrm{Al}) / \mathrm{Si}$ and the $\mathrm{Fe} / \mathrm{Al}$ molar ratios between the mother solution and the precipitates enable us to estimate uniquely the relative proportions of $\mathrm{Si}, \mathrm{Fe}$ and $\mathrm{Al}$ in hydrothermal water through chemical analysis of the precipitates.

\section{Conclusions}

The experimental study on the formation of the aluminosilicate precipitates provides us with important results on the relationship in the relative proportions of $\mathrm{Si}, \mathrm{Fe}$ and $\mathrm{Al}$ between the mother solution and the precipitate. The analytical procedure originated in this study enables us to determine precisely the relative proportions of $\mathrm{Si}, \mathrm{Fe}$ and $\mathrm{Al}$ in the precipitates with ease. Iron in the mother solutions is completely precipitated and $\mathrm{Al}$ is mostly deposited, however, $\mathrm{Si}$ is partly co-precipitated with $\mathrm{Fe}$ and $\mathrm{Al}$. Iron and/or $\mathrm{Al}$ make the precipitated proportion of Si markedly increase and trivalent $\mathrm{Fe}$ is equivalent to $\mathrm{Al}$ on the formation of the precipitates.

The relationships in the $(\mathrm{Fe}+\mathrm{Al}) / \mathrm{Si}$ and $\mathrm{Fe} / \mathrm{Al}$ molar ratios between the mother solutions and the precipitates give us that chemical analysis of the precipitates can reveal the relative proportions of $\mathrm{Si}, \mathrm{Fe}$ and $\mathrm{Al}$ in hydrothermal water discharged fron submarine volcanoes.

Acknowledgments. I would like to thank the reviewers for helpful comments on this paper.

\section{References}

Ichikuni, M., Incorporation of aluminum and iron into siliceous sinters, Chemical Geology, 6, 273-279, 1970.

Kamada, M., J. Ossaka, and T. Ozawa, Hydro-alumina-silicate generating from acidic hot spring water along the seashore of Iwojima volcano, Abstract of the Geochemical Sco. Japan, 158-161, 1964 (in Japanese).

Nogami, K., M. Yoshida, and J. Ossaka, Chemical composition of discolored seawater around Satsuma-Iwojima, Kagoshima, Japan, Bull. Volcanol. Soc. Japan, 38, 71-77, 1993.

Ossaka, J., The eruption of Nishinosima submarine volcano and geochemical study on the composition of the ejecta and the volcanic activity, Chemistry Today (Gendai Kagaku), 55, 12-20, 1975 (in Japanese).

Ossaka, J., Y. Ohira, J. Hirabayashi, and A. Mori, Comparison of amorphous hydro-alumina-silicate, formed in sea water with precipitated allophane, Jour. Min. Soc. Japan, 13, 178-186, 1977 (in Japanese).

Ossaka, J., J. Hirabayashi, K. Nogami, M. Tsuchide, and N. Adachi, Chemical composition of discolored seawater corresponding to activity of Fukutoku-Oka-no-Ba submarine volcano-as an index of submarine volcanism-, Bull. Volcanol. Soc. Japan, 41, 107-113, 1996 (in Japanese).

K. Nogami (e-mail: knogami@ksvo.titech.ac.jp) 